\title{
Cobalt released from stratiform sulfides by metamorphic remobilization: sources of orogenic sediment-hosted $\mathrm{Cu}$-Co deposits
}

\author{
ZHENGJIE QIU ${ }^{1}$ HONGRUI FAN ${ }^{1}$ ANDREW TOMKINS \\ XUAN LIU ${ }^{2}$ XIAOCHUN LI ${ }^{1}$ \\ ${ }^{1}$ Key Laboratory of Mineral Resources, Institute of Geology \\ and Geophysics, Chinese Academy of Sciences, Beijing, \\ 100029, China (qiuzhj@mail.iggcas.ac.cn) \\ ${ }^{2}$ School of Earth, Atmosphere and Environment, Monash \\ University, Clayton, Victoria 3800, Australia \\ (andy.tomkins@monash.edu)
}

Sediment-hosted copper deposits (SCDs) within Paleoproterozoic graphite schist and marble units in the south section of Tran-North China Orogen are important $\mathrm{Co}$ and $\mathrm{Cu}$ producers in China. The uncertainty of ore genesis models, including low-temperature stratiform sulfide diagenesis, a seafloor exhalative formation origin, and a metamorphosed sedimentary ore model, is primarily due to poor constrains regarding the mineralization timing and ore-forming process. In the graphite schist (protolith of sulfidic shale), the deformed stratiform pyrite (Py I) have high $\delta^{34} \mathrm{~S}$ values (SIMS: $22.75 \pm 0.57 \%$ ), indicating a complete bacterial sulfate reduction in the Paleoproterozoic sulfate-limited seawater. Lightly heavy iron isotope (in-situ $\delta^{56} \mathrm{Fe} 0.90 \pm$ $0.16 \%$ ) and cobalt-rich in Py I, suggest metal elements, including $\mathrm{Fe}, \mathrm{Co}, \mathrm{Ni}, \mathrm{Cu}$, preliminarily trapped in sulfidic ocean post great oxygenation event. Some Co-poor euhedral pyrite newly formed in metamorphic veinlets have slightly lighter $\delta^{34} \mathrm{~S}$ valuesand heavier $\delta^{56} \mathrm{Fe}$ values than Py $\mathrm{I}$, indicating cobalt is mobilized from Co-rich Py I through deformation and dissolution during orogenic fluid infiltration. recrystallized from Py I. The great variable of sulfur isotope in hydrothermal pyrite (Py-III) from mineralized veins, implies a thermochemical reduction of sulfate. Methane, from hydrothermal alteration of graphite, acted as a reducing agent for the thermal reduction of sulfate at high temperatures. New metamorphic apatite $\mathrm{U}-\mathrm{Pb}$ age $(1844 \pm 25 \mathrm{Ma})$ from metaevaporite is consistent with the molybdenite Re-Os isochore age $(1819 \pm 10 \mathrm{Ma})$ from sulfides bearing veins, further supporting a coincidence of orogenesis and mineralization. This study highlights the importance of metal pre-enrichment in the sulfidic ocean and upgrading through orogenic mobilization for the formation of SCDs hosted in the metamorphic terrance. Furthermore, it demonstrates the diverse styles of orogenic ore mineralization.

This research was supported by the National Science Foundation of China (41890833, 41902080). 